\title{
Iraqi EFL Students' Difficulties in Writing Composition: An Experimental Study (University of Baghdad)
}

\author{
Sura Muttlak Nasser ${ }^{1}$ \\ ${ }^{1}$ Department of English, College of Education for Women, University of Baghdad, Iraq \\ Correspondence: Sura Muttlak Nasser, Department of English, College of Education for Women, University of \\ Baghdad, Iraq. E-mail: sura.muttlak@coeduw.uobaghdad.edu.iq
}

Received: August 5, 2018

Accepted: September 27, 2018 Online Published: December 29, 2018

doi:10.5539/ijel.v9n1p178

URL: https://doi.org/10.5539/ijel.v9n1p178

\begin{abstract}
Iraqi EFL students face difficulties in writing composition, especially academic writing, which affects negatively their exam results. This study has been conducted in the Department of English at College of Education for Women, University of Baghdad, in order to identify first year EFL students' incompetence in writing. This may enhance their achievement by some weekly writing activities. It deals with Iraqi EFL students' difficulties in writing paragraphs such as descriptive, process, opinion, and factual paragraphs. The study aims to identify these difficulties and to suggest suitable solutions for them. The researcher perceives that it is necessary to enhance students' skills in writing because it is an important tool in their education progress. The study proved that the distinction is considerable. However, the researcher had a group sitting for pre and post- test to assess the output of the means of students' results.
\end{abstract}

Keywords: academic writing, handwriting writing, grammar, spelling

\section{Introduction}

Writing in a correct and good form is a big challenge for non- native students, especially to EFL (English Foreign Language) learners. Students at University of Baghdad learn English for a specific academic purpose to achieve the educational requirements Therefore; they need to be proficient in the writing process, elements, and characteristics such as formality, objectivity, and complexity in order to use the language correctly. Writing is seen as a tool of language learning and is considered a crucial skill in everyday life and a basic category of foreign language teaching, i.e., it is an important productive skill for EFL students in particular, for it is the main field for successful academic achievement in educational circles. Better usage of English language needs more practice, deep understanding, and massive comprehension of the target language vocabulary (Aajami, 2018a). Getting the exact meaning of each word helps in bettering up the students' performance in writing (Aajami, 2018b).

\subsection{Problem of the Study}

The researcher has observed that most students lack self- confidence when they are to write a paragraph such as (describing persons, places, giving opinion... etc.). The students are unable to express themselves in writing which hinders their creativity. Writing a composition needs the proficiency to use suitable vocabularies in a grammatical construction to form meaningful sentences of different types, the ability to choose appropriate conjunctions to link sentences, and the ability to choose correct punctuation marks. Since the duty of Department of English is to provide schools with adequate teachers of English, the researcher as a composition instructor recognizes that enhancing the students' writing is badly needed; graduates must be highly skilled in order to be able to teach the basis of writing.

\subsection{Significance of the Study}

The result of this study will be of benefits to EFL students to master good writing. Students who are skilled in writing can gain better scores than those who are unskilled. It might help students to improve their writing skills by using English. So, the basics of good writing should be taught and practiced from the early years of learning. It is also important for the instructors to generate and develop the methods of teaching writing rules. 


\subsection{Aims of the Study}

This study aims at:

- Diagnosing the problems and difficulties that face the Iraqi students at the Department of English.

- Identifying the way that students can write with no spelling or punctuation mistakes, compose meaningful sentences, using suitable conjunctions, using appropriate title and supporting sentences that fit the topic sentence.

\subsection{Limitations of the Study}

The participants were 30 female first- year students in the Department of English, College of Education for Women, University of Baghdad, Iraq. The study was conducted during the academic year 2017/2018. It was limited to teaching writing by the textbooks (The Elements of Style) and (College Writing from Paragraph to Essay).

\section{Literature Review}

\subsection{What Is Writing?}

Writing is the most significant skill in the process of learning a foreign language. It contains several sub-skills including composing, spelling, and handwriting. In order to produce any piece of writing, students should put their ideas in the correct order. Writing can be considered an important skill that needs more lucidity because there is not a direct communication between writers and readers.

Tuan (2010) indicates that writing is a skill in which the more students practice, the better they write. However, Al-Gharabally (2015) asserts that writing can be considered as "a means of evaluation" that' is why so many students feel they are being assessed when instructors examined what they have written.

Writing can occur in many shapes "creative, expository, editorial, epistle, etc." and it can be carried out in different ways "pen to paper, finger to keyboard" Alakeeli (2013, p. 74).

Pangaribuan and Manik (2018) define writing as a way that students use to express their ideas, thoughts, opinions, and experience. Also, they affirm that writing can be affected by some factors such as grammar, vocabularies, punctuation, recognition, and spelling. Reid (as cited in Damayanti, 2009) proposes three important causes for writing to explain, to entertain, and to persuade. While concentrating on the purpose of writing, student can move forward with his/ her writing by aiming at other stages.

The Writing skill must obtain accuracy and correctness in matters of grammar, punctuation, vocabulary, word order, spelling, capitalization ...etc. McDonough et.al, (2013) consider writing as a vehicle to language practice; as writers try to communicate their ideas and thoughts. They classify writing into six types: personal writing, public writing, creative writing, social writing, study writing, institutional writing and proposed levels of writing as shown in figure 1:

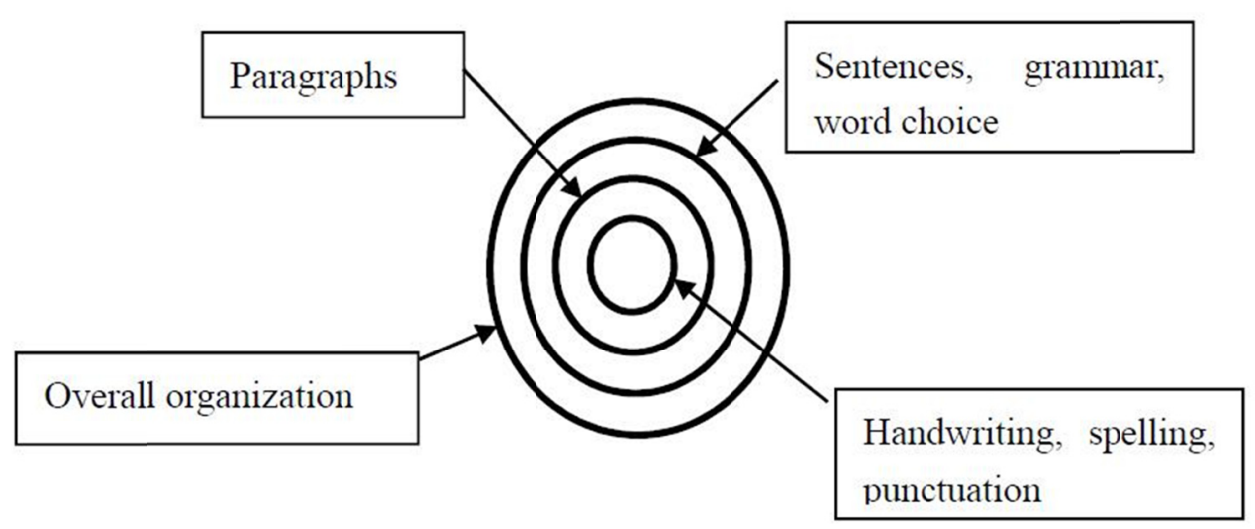

Figure 1. Levels of writing (after McDonough et al., 2013, p.188)

Writing is the most significant activity in the process of learning a foreign language. Through writing one can express ideas and facts in well-formed sentences that can be easily be perceived. 


\subsection{Steps of the Writing Process}

Zemach et al. (2003) state that writing paragraphs depend on four steps, that is, pre-writing, drafting, revising, and editing as clarified by Gebhard (2006) below:

Pre- writing: starts with choosing a topic, collecting and arranging ideas, in other words, it is the way of collecting ideas and thoughts about a specific topic. Mogahed (2013) claims that pre-writing indicates the first step of the writing process followed by the other steps.

Drafting: start your writing by using your notes about your thoughts (forming your sentences). Gebhard (2006) states that drafting means constructing a suitable sentence with logical meaning.

Revising: re-arranging ideas, forming, shaping meaning and enhancing language. It may involve providing additions or corrections, rethinking, or/ and rearranging details.

Editing: (Rewriting) this involves identifying and checking problems in structure context and grammar such as spelling, punctuation, subject-verb agreement, using in correct verb tenses, ...etc., and mechanics such as spelling and punctuation errors.

\subsection{What is Academic Writing?}

Academic writing is a means of success at higher educational levels if mastered carefully by students. Academic writing is a "mental and cognitive activity, since it is a product of the mind" (Al Fadda, 2012, p. 123) thus it is the representation of a student's mind workings as a mental and cognitive activity. Abdulkareem (2013) points out that academic writing has a basic function in learning a foreign language. EFL students must recognize the writing process, elements, and properties such as formality, objectivity, and complexity to practice the language distinctly and carefully, whereas $\mathrm{Li}(2007$, p. 43) assumes that writers' structures must identify some ideas about the identifications and expansion of English as second language contexts concerning the use of efficient lesson plans during teaching academic writing.

\subsection{Classification of Difficulties}

Iraqi students face some difficulties when writing paragraphs. In order to develop one's skills and ability in writing, one should first perceive problems regarding sentence structure, to write well-formed sentences. Alfaki (2015) reviews some linguistic difficulties and problems that EFL students face through the writing process such as grammatical problems, mechanical problems, sentence structure and diction problems.

Al Fada (2012) reports that transformation is a common writing difficulty EFL student face. Students believe that once they can produce sentences and paragraph in their native language (L1), they will transfer those to the target language. The reason why writing is a skill difficult to master is that, there are "cultural differences in the way academic register is perceived and understood in different countries" (Klimova, 2014, pp. 433-434). Additionally, social reasons can influence writing. They include negative view towards the target language, shortage of progressing in the FL, a big social and psychological gap between them and the "target culture, and, a lack of integrative instrumental motivation for learning" (Klimova, 2014, pp. 433-434).

Muhammed et al. (2016) reveal that student writers may face many writing difficulties and problems at different stages of their learning. These difficulties can be linguistic, psychological, cognitive and pedagogical Kellog and Raulerson (2007) assert the importance of "cognitive control" in writing, given factors of intentional exercises in the practice of college-level writers and proof of their importance. They also explain the problem of performance of intentional exercises in writing. They report that students must practice rather than be instructed so that they can develop "knowledge of correct spelling, punctuation, grammar, diction, thesis statements, topic sentences, and cohesive relates with a paragraph" (Kellog \& Raulerson, 2007, p. 23). All of these factors are so important but not enough for effective writing. Without practicing to use what the students know, their knowledge will not be active through writing paragraphs. Mohammad (2018) believes that the reason behind the students' errors is that English differs from Arabic and it has many different rules, patterns, and structures. The difficulties of the $1^{\text {st }}$ year students can be classified as shown below:

\subsubsection{Grammar}

According to Hajana (2006) an effective way to help EFL students in improving their grammar is to use students' writing as the fundamental tool for discussing grammatical concept meanings. Every acceptable paragraph is easy to be read and understood. Moreover, Abdulmajeed \& Hameed (2017) clarified that grammar is a subject that does not have an easy solution. It is difficult and complex. Grammatical difficulties can be classified as follows:

a. Misuse of tenses. 
b. Subject- verb agreement

c. Articles

d. Word order

e. Identifying sentence patterns

f. Identifying types of sentences.

\subsubsection{Spelling}

Bancha (2013) confirms that spelling mistakes appear when a student does not so focus properly because of weariness or neglecting correctness of words. Presenting any piece of writing depends on arranging ideas into a written form. According to the effect of other languages, the English spelling system is difficult and complex for Iraqi students. Alenazi (2018) assumes that Arabic is different from English especially with orthographic system (spelling system of a language) in that Arabic is read from right to left; therefore, he divided the problems into phonological and orthographical problems. Spelling difficulties can be classified as follows:

a. Wrong spelling

b. Confusing sounds and letters.

\subsubsection{Punctuation}

Punctuation "is more important than spelling" Betham (2011, p. 37). So punctuation marks provide words with meaning and they can change the meaning of words if they are not used correctly. According to Harmer (2007), language contains numerous important prospects such as punctuation and capitalization. In other words, when students try to write, they are learning more about the rules of punctuation and capitalization. They depend on writing for all the lessons, thus their exams require writing referred to by Meyers (2006) as writing for the sake of writing. Punctuation difficulties can be classified as follows"
a. Misuse of capitalization
b. Misuse of full stop
c. Misuse of commas

\subsubsection{Handwriting}

Handwriting is a means of expressing language. It is a tool that helps students express their ideas and for them it can cause shortage or pass the exam, since instructors do not spend time to decode what is written. Good writing includes the size, shape, and style of letters, and spacing between words which marks clear handwriting. Handwriting difficulties can be classified as follows:
a. Missing spaces
b. Letters are written incorrectly
c. style of letters

\section{Methodology}

To enhance the level of the target students, the researcher tries to use some activities and steps such as putting the students into small groups to discuss a particular question and suggest answers. Later one of them is asked to read the answers loudly and write the correct answers on the board. The researcher made a competition between groups such as asking the groups to think of various ideas, and write them, then asking the groups to read the answers loudly to write the most suitable one on the board. Additionally, the researcher asks students to write some topic sentences on papers, and exchange their papers with each other's giving them corrective feedback, providing them with some practical writing exercises and attracting the students' attention.

\section{Experiment}

The experiment of this study aims at identifying and classifying the difficulties committed by Iraqi students when writing. The researcher conducts an experimental group design of pre and post-tests to assess the experiment. The researcher thinks that an indicated design is adequate for the purpose of the current study. To achieve this aim, the researcher follows the following steps:

a) Thirty paragraph samples were taken as a data collection method (samples were chosen randomly).

b) At first, the students were given a pre-test in order to evaluate their competence in the basics of writing.

c) The researcher assigns the first ten minutes of each lecture for reviewing topics discussed in the previous 
lecture and asks the students to give some examples.

d) Students were divided into five groups; each group contains six students.

e) Each group will work hard to compete with other groups.

f) Focusing on the practical part, the researcher tries to discuss the rules of punctuation, pattern of sentences, types of different sentences, how to use conjunctions, how to use articles, and how to write paragraph by describing a picture by using visual aids with exercises and examples and teach students how to choose suitable sentences and suitable titles for their paragraph.

g) The students are asked to do exercises on each expression of information immediately after explaining it and receive feedback on their answers.

h) Results of pre and post-tests were quantitatively performed by using the statistical program SPSS.

The following steps represent procedures of effectiveness of repetition, competition, and feedback on helping students to improve their writing.

\subsection{The Research Instrument and Procedure}

A written test form was selected as the tool of the study. Pre and post-tests were formed to measure students' performance.

\subsection{Pre-test}

The test aimed to measure the student's efficiency in the basics of writing, and to identify the difficulties faced by the students of Department of English, College of Education for Women, University of Baghdad in writing appropriate English paragraphs. Results of pre- test were 30 marks gathered by the researcher. It showed that the students faced difficulties while writing and committing so many spelling mistakes. The scores indicated that the students failed to use correct grammar rules and punctuation marks. Furthermore, they revealed that the students were not able to organize their ideas appropriately in order to present themselves and convince the reader.

\subsection{Post-test}

Eight weeks of explanation were spent to explain the basics of writing. During this term the researcher focused on grammatical constructions, punctuation, and basic steps of writing. During this period, the students worked in groups and were asked to give examples and discuss them. The researcher showed the students pictures and asked them to describe those pictures. When it was time for the test, they performed the same task but separately. The results of the post-test indicated a noticeable progress in the students' writing. They were able to write correctly without spelling mistakes and with good punctuation. They also showed that they are able to express and organize their ideas clearly.

The following table presents a comparison between pre and post- test results. The marks are not written here to save space. SPSS statistical editor was used to analyze the collected data in both tests.

Table 1. The differences between pre and post- tests

\begin{tabular}{|c|c|c|c|c|c|c|}
\hline \multirow{2}{*}{\multicolumn{7}{|c|}{$\begin{array}{l}\text { [DataSet0] } \\
\text { One-Sample Statistics }\end{array}$}} \\
\hline & \multicolumn{6}{|c|}{ One-Sample Statistics } \\
\hline & $\mathrm{N}$ & Mean & Std. Deviation & \multicolumn{3}{|l|}{ Std. Error Mean } \\
\hline Pre-test & 30 & 9.1333 & 2.73840 & \multicolumn{3}{|l|}{.49996} \\
\hline Post-test & 30 & 12.6000 & 2.69866 & \multicolumn{3}{|l|}{.49271} \\
\hline \multicolumn{7}{|c|}{ One-Sample Test } \\
\hline & \multicolumn{6}{|c|}{ Test Value $=0.5$} \\
\hline & \multirow[t]{2}{*}{$\mathrm{t}$} & \multirow[t]{2}{*}{$\mathrm{df}$} & \multirow[t]{2}{*}{ Sig. (2-tailed) } & \multirow[t]{2}{*}{ Mean Difference } & \multicolumn{2}{|c|}{$95 \%$ Confidence Interval of the Difference } \\
\hline & & & & & Lower & Upper \\
\hline pretest & 17.268 & 29 & .000 & 8.63333 & 7.6108 & 9.6559 \\
\hline posttest & 24.558 & 29 & .000 & 12.10000 & 11.0923 & 13.1077 \\
\hline
\end{tabular}


In comparison, the scores of both tests indicated that the students suffered from difficulties in writing and the experiment proved effective in overcoming these difficulties.

\section{Results and Findings}

The main purpose of this study has been to diagnosis some difficulties of Iraqi students in learning English as a second language particularly in writing. It reveals that $1^{\text {st }}$-year students at Department of English, College of Education for Women, University of Baghdad have different writing difficulties. From the analysis of the findings, the researcher proposes that students' errors can be classified into grammar, punctuation, spelling, and handwriting errors.

In the Pre-test, each student committed 5-7 grammatical mistakes, while in the post-test, grammatical mistakes were fewer. Also, no attention was paid to capitalization, full stops, and commas in the pre-test, while the post-test showed a significant progress in students' awareness of the significance of punctuation marks.

There were more than 4 letters not written correctly in the pre-test; a problem which no longer existed in the post test answers.

Each sample group committed 4-5 spelling mistakes in Pre-test, while in the post-test spelling mistakes were fewer. The post-test results showed effective use of articles in students' writings.

Results of tests yielded effective outcomes because of using visual aids, and explaining a single item at a time directly followed by exercises which strongly assisted students to develop their writing.

\section{Conclusion}

This study concludes that:

a) Arranging paragraphs by using good style of word structures and correct conjunctions should be mastered and studied.

b) Most students commit mistakes in sentence structure, vocabulary, tenses, subject- verb agreement, articles, and word order.

c) Instructors need to work hard to improve and develop the students' writing and decrease the pressure that students feel when doing this activity.

d) The question that may be raised here is that what is the source of these errors? Are they inter- lingual or developmental in nature? It is important to say that most mistakes come from mother -tongue interference. It seems that students might have their first thought in their mother tongue and then translated it into English.

e) Using competitions, repetitions, visual aids, group work, and using effective feedback help students to improve their writing.

\section{References}

Aajami, R. F. (2018a). Applying Cognitive Linguistics to Enhance the Semantics of English at. International Journal of English Linguistics, 8(6), 185-192. https://doi.org/10.5539/ijel.v8n6p185

Aajami, R. F. (2018b). Cognitive Comprehension of "Beyond \& Behind": An Experimental Study. International Journal of English Linguistics, 8(6). 303-314. https://doi.org/10.5539/ijel.v8n6p303

Abdulkareem, M. N. (2013). An Investigation Study of Academic Writing Problems Faced by Arab Postgraduate Students at Universiti Teknologi Malysia (UTM). Theory and Practice in Language Studies, 3(9), 1552-1557. https://doi.org/10.4304/tpls.3.9.1552-1557

Abdulmajeed, R. K., \& Hameed, S. K. (2017). Using a Linguistic Theory of Humour in Teaching English Grammar. English Language Teaching, 10(2), 40-47. https://doi.org/10.5539/elt.v10n2p40

Al Fadda, H. (2012). Difficulties in Academic Writing: From the Perspective of King Saud University Postgraduate Students. English Language Teaching, 5(3), 123-130. https://doi.org/10.5539/elt.v5n3p123

Alakeeli, F. S. Sh. (2013). Examining Lexical and Grammatical Difficulties Encountered by Iraqi Students in Learning English as a Foreign Language. Unpublished thesis.St Clements University.

Alenazi, O. S. (2018). Spelling Difficulties Faced by Arab Learners of English as a Foreign Language. Arab World English Journal (AWEJ), 9(2), 118-126. https://doi.org/10.24093/awej/vol9no2.8

Alfaki, I. M. (2015). University Students' English Writing Problems: Diagnosis and Remedy. International Journal of English Language Teaching, 3(3), 40-52. 
Al-Gharabally, M. (2015). The Writing Difficulties Faced by L2 Learners and How to Minimize them. International Journal of English Language and Linguistics Research, 3(5), 42-49.

Bancha, W. (2013). What Causes Spelling Errors of the Thai EFL Students?. ARECLS, 10, 107-129. Retrieved from http://research.ncl.ac.uk/ARECLS/volume_10/bancha_vol10.pdf

Betham, E. (2011). Punctuation Today: A Qualitative Study. Skepsi, 4(2).

Damayanti, Y. (2009). Micro and Macro Skills of Writing Found in the Writing Exercises of the Bridge English Competence for SMP grade VIII.

Fareed, M., Ashraf, A., \& Bilal, M. (2016). ESL Learners' Writing Skills: Problems, Factors and Suggestions. Journal of Education and Social Sciences, 4(2), 81-92. https://doi.org/10.20547/jess0421604201

Gebhard, J. G. (2006). Teaching English as a Foreign or Second Language. Michigan. The University of Michigan. https://doi.org/10.3998/mpub.147778

Hajana, O. H. O. (2006). The Relationship between Grammatical Competence and Writing Quality. Unpublished Thesis, College of Graduate Studies, University of Khartoum.

Harmer, J. (2007). The practice of English Language Teaching. Pearson Education Ltd.

Kellog \& Raulerson III. (2007). Improving the Writing Skills of College Students. Psychonomic Bulletin \& Review, 14(2), 237-242. https://doi.org/10.3758/BF03194058

Klimova, B. (2014). Constraints and Difficulties in the Process of Writing Acquisition. Procedia - Social and Behavioral Sciences, 122, 433-437. https://doi.org/10.1016/j.sbspro.2014.01.1367

Li, X. (2007). Identities and Beliefs in ESL Writing: From Product to Processes. TESL Canada Journal, 25(1), 41-64. https://doi.org/10.18806/tesl.v25i1.107

McDonough, J., Shaw, C., \& Masuhara, H. (2013). Materials and Methods in ELT. A Teacher's Guide (3rd ed.). Blackwell.

Meyers, A. (2006). Composing with Confidence: Writing Effective Paragraphs and Essays. Harlow: Pearson Education Ltd.

Mogahed, M. M. (2013). Planning out Pre- writing Activities. International Journal of English and Literature, 4(3), 60-68.

Mohammed, M. Q. (2018). Difficulties of Iraqi EFL Learners with Substance Errors in Writing. Journal of Applied Linguistics and Language Research, 5(3), 131-147.

Pangaribuan, T., \& Manik, S. (2018). The Effect of Buzz Group Technique and Clustering Technique in Teaching Writing at First Class of SMA HKBP I Tarutung. English Language Teaching, 11(1). https://doi.org/10.5539/elt.v11n1p164

Strunk, W. J. R., \& White, E. B. (2000). The Elements of Style. Longman.

Tuan, L. T. (2010). Enhancing EFL Learners' Skill via Journal Writing. English Language Teaching, 3(3), 81-88. https://doi.org/10.5539/elt.v3n3p81

Zemach, D. E., \& Rumisek, L. A. (2003). College Writing from Paragraph to Essay. Macmillan.

\section{Copyrights}

Copyright for this article is retained by the author, with first publication rights granted to the journal.

This is an open-access article distributed under the terms and conditions of the Creative Commons Attribution license (http://creativecommons.org/licenses/by/4.0/). 